811.163.41'366.582

https://doi.org/10.18485/sj.2021.26.1.20

ЂОРЂЕ М. ГЕНОВИЪ

Универзитет у Београду

Филолошки факултет
Оригинални научни рад

Примљен: 13. 10. 2020.

Прихваћен: 12. 1. 2021.

\title{
О ОСНОВНИМ ЗНАЧЕЫИМА И ОДНОСИМА УНУТАР СИСТЕМА ПРЕТЕРИТАЛНИХ ВРЕМЕНА У СРПСКОМ ЈЕЗИКУ
}

Рад се бави анализом значења и односа међу базичним члановима система претериталних времена у српском језику - имперфектом, аористом и перфектом. Користећи и на појединим местима настављајући се на ставове ранијих истраживача, аутор настоји да реконструише полазне значењске карактеристике трију глаголских облика са циљем бољег разумевања еволуције система, при чему се у првом реду мисли на процесе попут губљења имперфекта, специјализације аориста, те уопштавања перфекта. Преовладава утисак да су пресудну улогу у трансформисању значењских особина облика за исказивање прошлих радњи одиграла од почетка присутна питања темпоралне оријентације и видске (не) рестриктивности. За најважнији резултат оваквих тенденција може се узети чињеница да је перфекат, као прогресивно темпорално оријентисан и видски нерестриктиван облик, однео превагу над осталим члановима система и тиме у даљем току еволуције почео пресудно утицати на његов даљи развитак.

Кључне речи: српски језик, глаголска времена, претеритални систем, имперфекат, аорист, перфекат. 
1. Увод. Иако расправа о основним значењима глаголских времена и њиховим међусобним односима унутар темпоралног система у србистици има традицију дужу од једног столећа, никако се не би могло рећи да су на питања која су у склопу ње истраживачи постављали дати коначни одговори. Ширина и комплексност теме, као и различити углови из којих је дата проблематика посматрана условили су настанак мноштва различитих закључака, некад мање, а некад више међусобно повезаних. ${ }^{1}$ Међутим, стиче се утисак да нигде наведене речи нису толико дошле до изражаја као при истраживању једног од темпоралних подсистема - подсистема претериталних времена у српском језику. Број чланова подсистема, неухватљивост тананих значењских нијанси међу њима, недовољно расветљени структурни односи (како унутар глаголских облика, тако и међу глаголским облицима), као и непримењивост појединих општеприхваћених поставки и закључака проистеклих из многобројних расправа и чланака на ову тему, спадају у разлоге који дискусију о значењима и односима унутар претериталног система и даље чине отвореном.

Стога ће, следећи наведене разлоге, циљ овог рада бити да на ограниченом простору, користећи се неким од најзначајнијих закључака произашлих из ранијих истраживања система претериталних времена у српском језику, изнесе унеколико ново схватање природе претериталних времена, као и њихових међусобних односа. Нагласак ће притом највише бити стављен на судбину тзв. предњег плана система, кога, према схватању Милке Ивић (1958), чине три базична претеритална облика - имперфекат, аорист и перфекат. Полазећи од природе сваког од ова три облика, напослетку ће бити начињен покушај расветљавања разлога који су довели до потискивања и специјализације једних, те до ширења и уопштавања других претериталних форми. Уз све до сад речено, треба напоменути како овај рад ни својим обимом ни количином грађе која се у њему износи не претендује да пружи у овом смислу коначне одговоре, већ пре има за циљ да, ослањајући се на дугу традицију разматрања овог питања и њему сличних, пружи инспирацију и назначи основне правце за будућа истраживања.

2. Око базичних значења претерита. Насупрот добро постављеним Белићевим категоријама индикатива и релатива (Белић 1925-1926; 1926-1927), које су дискусију о значењу глаголских времена у српском језику сразмерно рано извеле на прави пут, стајала је неодређеност категорије релатива и њене даље последице (в. Стевановић 1967, па донекле и Вуковић 1967). Упркос ваљано решеном питању индикатива (од тада апсолутива) и релатива, Сладојевић (1966) није дао систематичнија решења у вези са значењима појединих глаголских облика. Иако је изнео низ значајних констатација у вези са импер-

${ }^{1}$ Детаљније о главним токовима дискусије, нерешеним проблемима, као и путоказима за даље проучавање временских глаголских облика у српском језику в. у Милошевић 1978. 
фектом, Вуковић (1967) није, чини се, успео до краја разрадити своју тезу о систему прошлих времена, чему је најбољи показатељ одређење места аориста у том систему. Исто се може приметити и за чланак Милке Ивић (1958), чија би даља разрада вероватно привела дискусију знатно ближе крају. Запажања везана за аорист помогла су да се донекле разуме његова прагматичка вредност, али се анализа његових граматичких компоненти често чини или непотпуном или неодговарајућом (нпр. посматрање аориста као тзв. нултог времена). Анализа перфекатских значења и дефинисање поља перфектности значајни су за разумевање синхроног стања, али изостаје утврђивање полазног поља перфектности, на основу ког би се могли изводити далекосежнији закључци. ${ }^{2}$

Па ипак, виђење тзв. предњег плана система прошлих времена које ће бити изнесено у овом раду засновано је на провереним закључцима донетим у поменутој дискусији. У првом реду биће уважена Сладојевићева схватања о апсолутном индикативу, будући да она најједноставније а опет најучинковитије отклањају претпоставке о релативном карактеру употребе претерита. Унутар њих, временска локализација се не посматра као контекстуализација, већ као чиста временска локализација, прецизирање. ${ }^{3}$ Општи закључци Милке Ивић о динамичности аориста и имперфекта такође су драгоцени. Они у први план стављају најмаркантнију особеност ова два облика и повезују је са формалним ограничењима (однос перфекат : крњи перфекат). Вуковићево одређење имперфекта као трајне прошле радње, при чему је фокус на њеном току, а не на њеним границама, уз напомене о презентској природи имперфекта, такође добијају свој пун значај. Као што је већ напоменуто, Стојановићева запажања о садашњем стању српског перфекта верно приказују тренутну слику и ваљано назначавају даље развојне тенденције.

Beћ је раније истакнуто како ће највише пажње у овом раду бити посвећено тзв. предњем плану система претериталних времена. Оправдање оваквог избора лежи у примарној улози његових чланова - имперфекта, аориста и перфекта - у односу на изведене елементе система, као што су плусквамперфекат или крњи перфекат. ${ }^{4}$ Стога ће се предстојећа анализа највише на њих усредсредити, и то овим редом: имперфекат, аорист, перфекат.

${ }^{2}$ Притом се схватања о „урођеној” експресивности аориста (Стојановић 2018: 131), која остављају по страни питање о узроцима који су довели до експресивности једног глаголског облика, чине донекле преурањеним.

${ }^{3}$ Под контекстуализацијом се подразумева конструкција по којој је нпр. сваки временски локализован аорист релативан (пр. Ја јуче узех књигу од Марка.), чиме се теза о значењу непосредне прошлости овог облика представља као неупитна.

${ }^{4}$ Оваквим избором се никако не жели умањити значај који изведени облици имају у сагледавању еволуције система претериталних времена. Напротив, њиме се жели успоставити основа за боље разумевање њихове улоге. 
2.1. ИмПЕРФЕкАт. Иако је значење имперфекта још од првих истраживања изазивало многе недоумице и опречна мишљења, чини се да је већину његових карактеристика најбоље уочио Јован Вуковић (1967: 107-245). У први план се истиче својеврсна паралелност у односу на својства (апсолутног) презента: видска рестрикција на несвршене глаголе, фокусирање на ток радње, а не на њене границе или завршетак. Услед чињенице да се „роnaša kao relativni prezent" (Вуковић 1967: 110), аутор је целокупну природу овог облика одредио као релативну (стр. 191 и даље). Међутим, на овом месту, уз уважавање свих осталих Вуковићевих схватања значења имперфекта, чини се важним нагласити следеће:

1) имперфекат, у великој мери значењски истоветан релативном презенту, ипак не може бити инхерентно релативан, јер је његова основна функција исказивање прошлих радњи, док то са презентом није случај; из поменутог разлога, осим у специфичним условима и при модалној употреби, треба рећи да је имперфекат апсолутно глаголско време (као што сматра и Сладојевић, мада то нигде експлицитно не формулише);

2) иако и Вуковић и Сладојевић наглашавају моменат доживљености 6 имперфекта (нпр. Вуковић 1967: 393; Сладојевић 1953-1954: 213), те га заједно са аористом на тај начин супротстављају перфекту, пре би се могло рећи да је у овим случајевима у питању прагматичка, а не семантичка компонента; на овакав закључак упућују карактеристике наведене у Сладојевић 1953-1954: 214 (т. 4 и 5); наиме, ако се неке од значењских карактеристика у појединим ситуацијама могу пренебрегнути, не може бити речи о семантици.

Мада је код Вуковића више пута наглашен моменат „преношења” у прошлост (нпр. Вуковић 1967: 212), ни на једном месту такво преношење, са свим осталим његовим особинама, није графички приказано. ${ }^{7}$ Овде је, међутим, упутно дати један такав приказ, уз напомену да ће исто бити учињено и у случају остала два глаголска облика. Овом приликом одабрана су два примера, један Вуковићев (1) и један Ивићев (2): ${ }^{8}$

${ }^{5}$ О релативној природи имперфекта говори се, из нешто другачије перспективе и по угледу на стање у француском језику, и у новијој литератури о овом глаголском облику (в. нпр. Станојевић 2019: 285).

${ }^{6}$ У овом раду појам доживљености неће бити сагледаван из наратолошке, већ из граматичко-семантичке перспективе.

${ }^{7}$ При разматрању темпоралне проблематике поменута пракса није страна. У нашем случају као инспирација је послужио пример из Бунина 1959.

${ }^{8}$ Будући да смо тезу о напоредности из које проистиче релативност имперфекта одбацили, у складу са циљевима овог рада биће дате само (готово) минималне употребе имперфекта. Исто ће бити учињено у случају аориста, одн. перфекта. Материјал се, имајући у виду виталност овог глаголског облика, наводи из аутентичне дијалекатске грађе. 
(1) Никад беспослен не стајаше. (Вуковић 1967: 162)

(2) Инӓ (=једна) дивоิјка идаิн мушка̂р тӓмо се јуิ баву (=љубљаху). (Ивић П. 1953-1954: 232)

У оба случаја ситуација је иста: говорно лице X упућује на радњу (стајати, љубити се) у прошлости (у случају имперфекта на то упућује формант -ше (3. л. јд. имп.), тј. -ву [<-ху<-хв] (3. л. мн. имп.)) која је трајала (информацију о томе даје несвршени вид глагола), а њене границе се ни на који начин не спецификују. На графикону бр. 1 пуном хоризонталном линијом в приказана је временска оса са тачком ТГ (тренутак говора). Паралелно испод пуне линије налази се испрекидана линија $\boldsymbol{u}$, која означава радњу обележену обликом имперфекта. Испрекиданошћу линије сугерише се да је радња у току. Шрафура изнад линије $\boldsymbol{u}$ указује посредно на временску локализацију. Вектор испрекидане линије означава управљеност прошле радње ка ТГ (и даље), што значи да она може трајати у самом ТГ (али и након њега; о томе се информација обликом имперфекта не даје). Лучна линија која креће из тачке $T Г$ и упућује на испрекидану линију представља преношење фокуса говорног лица $\mathrm{X}$ из $T Г$ у прошлост. Будући да је лучна линија усмерена лево, тј. ка делу осе који представља прошлост у односу на $T \Gamma$, овакав тип темпоралног усмерења биће назван регресивним.

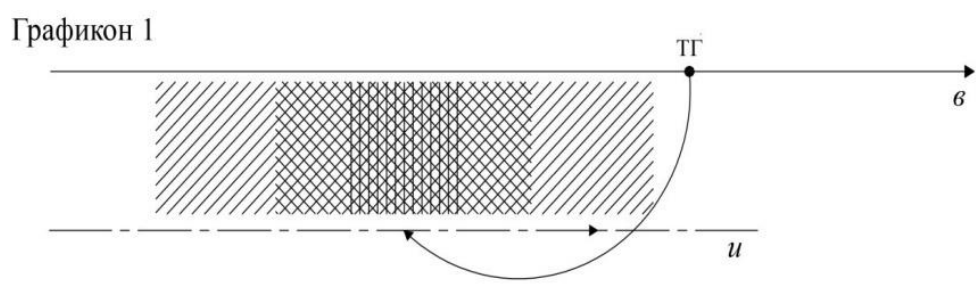

Никад беспослен не стајаше.

2.2. Аорист. Од почетака истраживања аориста у домаћој литератури две чињенице су неспорне: (1) овај облик служи за обележавање прошлих радњи и (2) од перфекта се разликује извесном непосредношћу, живошћу или динамиком. И док прва тврдња свакако не може, барем у општим цртама, бити доведена у сумњу, друга је на различите начине оспоравана, преиспитивана или преименована. На овом месту чини се прикладним изнети неколико запажања о поменутом питању:

1) развијану још од Белићевих истраживања, теорију о аорисном значењу непосредне прошлости (уп. Белић 1925-1926; 1926-1927) по свему судећи не подржава минимални контекст: у реченици (3) Марко узе јабуку ни на који начин се обликом аориста не указује на блискост/ удаљеност прошле радње од ТГ; стога се, по овом питању, може 
ићи за Сладојевићевом констатацијом како „о томе колико је радња удаљена од момента говора говорног лииа, аористом се, по нашем мишьељу, не казује ништа" [истицање П. С.] (Сладојевић 1955-1956: 131 и даље за примере); 9

2) уместо критеријума непосредности у појединим радовима, као ново дистинктивно својство у односу на перфекат, јавља се доживљеност, преко које се аорист, заједно с имперфектом, супротставља перфекту (в. нпр. Сладојевић 1953-1954: 213); са друге стране, неки аутори (в. Вуковић 1967: 393) аорист и имперфекат разликују на основу параметра апсолутно : релативно глаголско време. Чини се да ниједан од поменутих критеријума не даје потпуно објашњење. У првом случају (доживљеност), важи исто што и за имперфекат (в. 2.1. т. 2, уз нап. бр. 6): уколико наведени Сладојевићеви критеријуми објашњавају његово виђење појма доживљености, то онда није семантичка, већ прагматичка компонента. ${ }^{10} \mathrm{O}$ другом случају је већ раније било речи, тако да ће овде бити само поновљен главни закључак: и имперфекат и аорист су апсолутна глаголска времена;

3) блиско оваквом проблему одређивања значења глаголских времена чини се тумачење аориста као „нултог времена”, при чему се он на овај начин успоставља као минималан пар презента (од кога га, опет, одваја инхерентна перфективност) (Арсенијевић 2013: 256-257); међутим, против ове тезе говори чињеница да се аористом, у основним типовима употребе, превасходно жели исказати прошла радња, те да темпорална семантика и даље игра битну улогу. ${ }^{11}$ Узроци за „слободан однос аориста према времену говорења”, које аутор приписује „нултој временској спецификацији” (257), пре би се могли тражити у особеностима развоја темпоралног система српског језика и општим значењским карактеристикама овог глаголског облика.

Након ових запажања оправдано је поставити питање: у чему се, заправо, огледа особеност аориста?

Заправо, најцелисходније је употребу овог облика спецификовати у односу на имперфекат: док је имперфекат усредсређен на ток прошле радње, без давања било какве врсте информација о њеним границама или њеном завршетку, аорист је (и у случају кад се гради од несвршених глагола) усредсређен или на „тренутак свршетка глаголске радње” (код имперфективних глагола) или

${ }^{9}$ Чини се да је овакав неспоразум при одређивању значења аориста потекао из поређења са перфектом (о томе више речи ниже).

${ }^{10} \mathrm{O}$ неопходности разграничења семантичких и прагматичких компоненти, уз нарочит осврт на статус аориста по том питању, в. Станојевић 2007: 128-130.

${ }^{11}$ О проблематичности одређења аориста као „нултог времена” в. детаљније Станојевић 2019: 321-325. 
на „тренутак извршења глаголске радње” [истицање А. Б.] (код перфективних глагола) (Белић 1925-1926: 177). С наведеним се у начелу слажу и Вуковићеве констатације (Вуковић 1967: 214-231), а на исти закључак упућују и лако проверива формална ограничења при употреби овог облика. Тако се у временској реченици са везником док (најчешће се њиме сигнализира симултаност радње субординиране и хиперординиране реченице) предикат може наћи и у облику имперфекта и у облику перфекта, али не и у облику аориста:

(4) Док с еђаше на тераси, људи су пролазили улицом.

(5) Док је седео на тераси, људи су пролазили улицом.

(6) *Док седе на тераси, људи су пролазили улицом.

Стога треба још једном нагласити: и у случају аориста свршених и у случају аориста несвршених глагола фокус се ставља на финалну секвенцу, тј. на тачку након које се одређена радња, прошла у односу на ТГ, сматра завршеном.

Што се тиче разликовања аориста и перфекта, ситуација се чини сложенијом. Наиме, оба облика исказују прошле радње које се могу сматрати завршеним и оба облика, за разлику од имперфекта, могу се градити од глагола и свршеног и несвршеног вида. Притом, подела по којој Вуковић супротставља аорист као специфичну према перфекту као општој прошлости (при чему се, као и код Сладојевића, за дубински критеријум узима доживљеност) (Vuković 1967: 392-393) може бити валидна ако се у обзир узму синхроне прилике, али не може објаснити низ разлика које су дефинитивно међу њима присутне, а чини се да происходе из њихових, у суштини, различитих усмерења. Стога се за ову прилику као најприкладнија разлика између два облика може узети параметар Милке Ивић - динамичност - D, коју аорист /+/ (као и имперфекат /+/) поседује у односу на перфекат /-/. Овде пажњу не изазива критеријум који лежи у подлози овакве диференцијације (доживљеност), већ пре констатација да аорист „дочарава у извесном смислу непосредан доживљај прошлости, најсвежији утисак о готовости" [истицање М. И.] (Ивић М. 1958: 143), чиме се веома приближава имперфекатском „преношењу у прошлост”. Како у питању није само тражење паралела међу простим претеритима, у великој мери показују и новија, на обимном корпусу заснована истраживања старословенског перфекта. Тако се на основу опширне анализе четири споменика са почетака словенске писмености (Синајски псалтир, Синајски евхологиј, Супрасаљски зборник и Маријино јеванђеље), између осталог, закључује како глаголи у аористу описују догађаје „конкретные, локализуемые во времени ситуации, которые, с точки зрения говорящего, имели место в физическом мире” (Плунгјан/Урманчијева 2017: 29), док форме перфекта „не називают какую-ту конкретную ситуацию, а являются резюмирующей характеристикой некоторого события" (42). На овај начин постаје јасно да се аорист и перфекат разликују по типу основног усмерења. 
Будући да се из претходног може видети како се при употреби аориста нагласак ставља на прошли догађај, а не на одређени вид карактеристике/ искуства присутног или одлучујућег у ТГ, и његов ћемо тип темпоралног усмерења назвати регресивним.

На графиконима $2 a$ и 26 пуном хоризонталном линијом в приказана је временска оса са тачком $T Г$. У првом случају (графикон 2a, реченица Јабука naдe ca дрвета), из тачке ТГ полази вектор усмерен лево према тачки $\boldsymbol{A}($ орист) $\boldsymbol{c}$ (вршени), чиме се жели нагласити регресивно темпорално усмерење. ${ }^{12}$ Две вертикалне испрекидане линије са обе стране тачке $A c$ упућују на фокус ка извршењу радње. У другом случају (2б, реченица Седеше на тераси иеео дан) паралелно испод линије в наћи ће се испрекидана линија са вектором усмереним ка крајњој тачки $\boldsymbol{A}$ (орист) $\boldsymbol{\boldsymbol { \mu }}$ (есвршени). И овде ће лучна линија бити усмерена према $A н$, при чему је поново фокус на финалној секвенци ситуације, тј. њеном свршетку.

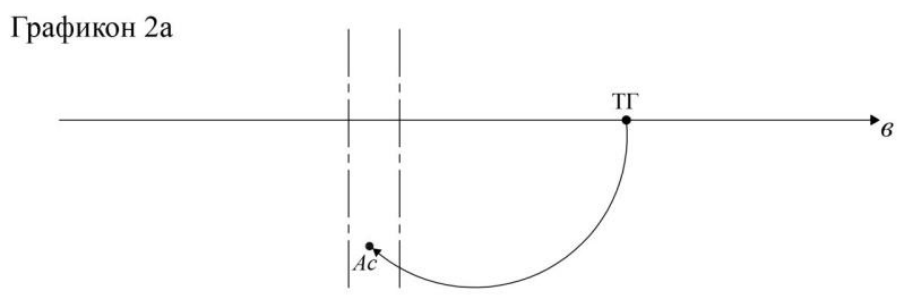

Јабука паде са дрвета.

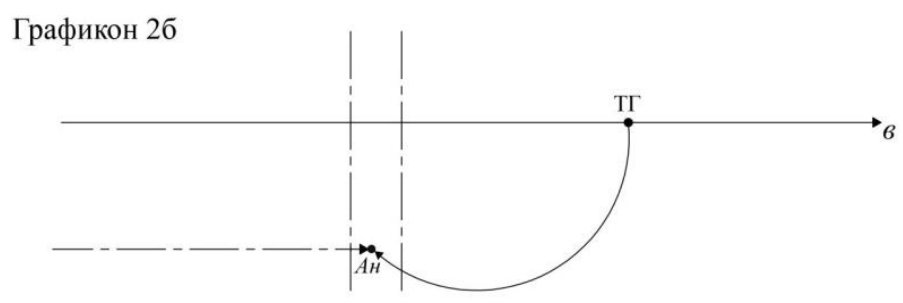

Седеше на тераси цео дан.

2.3. ПеРфЕкАт. Испитивања значења перфекта, најфреквентнијег глаголског облика за исказивање прошлих радњи у српском језику, већ од самих почетака су усмеравана у два правца: а) ка ужем одређењу прототипне перфектне семантике и последично б) ка разлозима ширења перфекта унутар система

\footnotetext{
${ }^{12}$ Приказивање свршене радње као тачке у времену изазвано је само практичним разлозима - са циљем што лакшег и сликовитијег приказивања типа ситуације.
} 
претериталних времена. Овом приликом више пажње ће бити поклоњено ужем одређењу перфектне семантике.

Традиционално и једно од најтипичнијих схватања семантике перфекта, како из дијахроне тако и из синхроне перспективе, јесте значење резултативности. Њиме су на најједноставнији начин спојене две несумњиве особине перфекта: „прво, да има извесне везе са садашњошћу и, друго, да партицип значи радњу у прошлости која се временски према садашњости ближе не одређује” (Белић 1926-1927: 122). Ипак, већ је сразмерно рано (и на истом месту) сам Белић утврдио да се резултативно значење углавном везује за перфекат свршених глагола, што значи да „сам перфективни глагол има често резултативно значење и по томе сваки израз у коме је он мора имати то значење; али сам перфекат у разговору (т.j. у синтаксичком индикативу) никада не даје значење „резултативности,” ако га нема у самом глаголу” [истицање А. Б.] (121). Новија истраживања српског перфекта везаност резултативности за свршене глаголе само потврђују, па тако „у минималном контексту глаголи свршеног вида имају значење перфектности резултата, ређе квалификативноперфектно, док глаголи несвршеног вида по правилу имају значење перфектности искуства, ређе чињеничноперфектно или чисто претеритално значење" (Стојановић 2018: 117). ${ }^{13}$ Везивање језгреног значења перфекта за компоненту резултативности није у потпуности оправдано ни са дијахроног становишта, будући да њу у старословенским текстовима може доносити (и то сразмерно чешће) и аорист, такође грађен од свршених глагола (в. Плунгјан/Урманчијева 2017: 32, 50). ${ }^{14}$

Стога, има разлога поставити питање на који се начин могу одредити основна својства перфекта. Пажња ће прво бити обраћена на стање у споменицима ране словенске писмености. На приличној количини грађе, одбацујући тезу о резултативу и текућој релевантности као иманентно перфекатским значењским компонентама, В. Плунгјан и А. Урманчијева примећују на примерима употребе глагола светити из Синајског требника како перфекатски облик „имеет прагматические последствия, релевантные для настоящего момента" (Плунгјан/Урманчијева 2017: 34), док се исто то не може закључити и за аорист. На даљем низу примера употребе перфекта (најчешће анализираних у односу на одговарајуће аорисне форме) закључује се како „он демонстрирует прежде всего характеризационные и экзистенциальные употребления” (50), при чему често „используется для описания ситуаций, которые не имеют четкой временской локализации. Так тяготение к перфектной форме демонстрируют предикаты, описывающее существенное изменение состояния топика данного

${ }^{13}$ Треба ипак напоменути да је у српском језику резултативно значење могуће изразити и помоћу глагола несвршеног вида, и то у склопу тзв. искуственог перфекта (детаљније о овоме в. Станојевић/Ђурић 2019: 228-231).

${ }^{14} \mathrm{У}$ истом раду је утврђено да се аористом може иразити и друго традиционално перфектно значење - значење текуће релеватности (Плунгјан/Урманчијева 2017: 32). 
фрагмента” (51). Упоређене са констатацијама А. Белића (,перфекат значи [...] везу у садашњости вршене или извршене радње у прошлости са субјектом" (Белић 1926-1927: 122)), М. Ивић (,да би моменат конкретизације вршења, тј. сам факат радње [истицање М. И.] (D обележје) добио у природи перфекта примарни, релевантан значај (вредност D/+/) потребно би било да моменат временског одмеравања постане од секундарне важности" (Ивић М. 1958: 145)) или С. Стојановића (,у минималном контексту као подразумевана референтна тачка [перфекта] биће узето време говорења" (2018: 114)) о природи перфекта, ове напомене воде у једном правцу: за разлику од имперфекта и аориста, чије је темпорално усмерење у односу на ТГ регресивно, темпорално усмерење перфекта је прогресивно. Дакле, прогресивно темпорално усмерење перфекат има јер се радња њиме обележена, иако прошла, повезује са ТГ (а не обрнуто), при чему се потпуно пренебрегава информација о евентуалној временској локализацији те радње. Притом, будући да се радња обележена перфектом увек сматра завршеном (или бар заустављеном), ${ }^{15}$ између њеног краја и ТГ неминовно постоји - макар и минимална - временска дистанца. Овиме се перфекат најдиректније одваја од аориста, јер овај, будући да има регресивно темпорално усмерење, не оставља простор за стварање временске дистанце (из чега касније произлази и другачији развој прагматичких импликација). Чињеницу да између радње у перфекту и ТГ увек постоји макар и најмања дистанца, чини се, показују примери П. Ивића (реченице (7), (8) из 1954-1954: 256) и С. Стојановића (реченица (9) из 2018: 118)

(7) Дӧста си се задери вао с моิм.

(8) Дӧста си је глӓдиво, удрй је.

(9) Подршку кандидатури Слободана Милошевића за председника Савезне Републике Југославије [...] својим потписима је до данас дало око 10.000 грађана [...]. ${ }^{16}$

Будући да се радње у реченицама (7), (8), (9) протежу све до садашњег тренутка, маркерима доста и до данас жели се означити прекид трајања тих радњи пре њиховог изрицања.

Тврдње изнете у Плунгјан/Урманчијева 2017 о временској нелокализованости радње означене перфектом потврђује и следећа констатација П. Ивића:

„[...] на више места смо сретали употребу перфекта у примерима где се истиче, који пут не без извесне емфазе, да се нека радња извршила или није извршила, при чему сви други моменти долазе у позадину [истицање Ђ. Г.]. Нарочито типичну ситуацију ове врсте претстављају замерке, пребацивања, грдње, свађе. Ту долази редовно перфекат,

${ }^{15}$ Као и у случају аориста, ни овде вид не игра никакву улогу (више о овоме в. у Vuković 1967: 120-121, 214-231).

${ }^{16}$ У овом случају [истицање Ђ. Г.] реченице са предикатом у аористу и аутор наводи као нетипичне. 
опет без обзира на то да ли је говорно лице својим очима видело поступак због којег протестује [...]” (Ивић П. 1953-1954: 256)

У реченицама овог типа тачна локализација на временској оси је непотребна, тј. једино је важно прецизирати да је радња извршена у прошлости, а да се у ТГ из неког разлога она помиње:

(10) Тй нйсй га леิипо полй ла.

(11) Јӧш ни́си се дй гаво!

Из реченог се види да одређивање основне семантике перфекта у кључу резултативности или текуће релевантности није у основи нетачно, али је непрецизно, будући да ће као такво пре бити изведено него основно.

Помоћу наведених критеријума чини се лакшим дати одговарајуће графиконе $3 a$ и 36 , који осликавају (основни) механизам функционисања перфекта. На графикону $3 a$ (реченица Раднички је испао из лиге) дата је временска оса 6 , са тачком $T Г$. Испод лево дата је тачка П(ерфекат)с(вршени), која се лучном линијом везује са тачком ТГ (према којој је усмерен и вектор). Линије која вертикално везује тачку Пс са временском осом нема, будући да временска локализација у минималном контексту није релевантна. На графикону 36 (реченица Играли смо кошарку у дворишту) уместо тачке испод временске осе наћи ће се секвенца П(ерфекат) лучном линијом према тачки $T Г$. Ни секвенца Пн није ни на који начин повезана са временском осом. Још једном треба нагласити да ће се овакав вид темпоралне оријентације називати прогресивним.

Графикон 3a

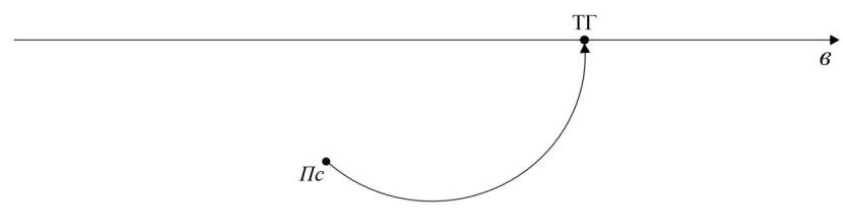

Раднички је испао из лиге.

Графикон 36

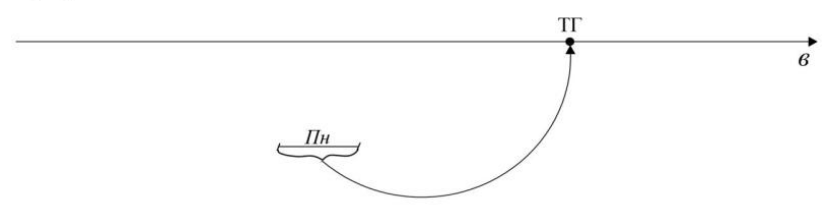

Играли смо кошарку у дворишту. 
3. Закључак. Након свега реченог, базични односи између претериталних времена у српском језику могу се илустровати следећом табелом:

\begin{tabular}{|c|c|c|c|c|}
\hline & $\begin{array}{c}\text { темпорална } \\
\text { оријентација }\end{array}$ & $\begin{array}{c}\text { завршеност } \\
\text { радње }\end{array}$ & $\begin{array}{c}\text { видска } \\
\text { рестрикција }\end{array}$ & $\begin{array}{c}\text { временска } \\
\text { локализација }\end{array}$ \\
\hline имперфекат & - & 0 & + & $(+)$ \\
\hline аорист & - & ++ & - & $(+)$ \\
\hline перфекат & + & + & - & - \\
\hline
\end{tabular}

Табела бр. 1: базични односи међу претериталним временима у српском језику

Имперфекат: регресивна /-/ темпорална оријентација; не узима се у обзир /0/ завршеност радње; видску рестрикцију /+/ на несвршене глаголе; имплицитно је присутна /(+)/ временска локализација.

Аорист: регресивна /-/ темпорална оријентација; радња је завршена, при чему се нарочито у обзир узима њена финална секвенца/тачка /++/; нема /-/ видску рестрикцију (може се градити од глагола оба вида); имплицитно је присутна /(+)/ временска локализација.

Перфекат: прогресивна /+/ темпорална оријентација; радња је завршена /+/; нема /-/ видску рестрикцију (може се градити од глагола оба вида); радња није /-/ временски локализована.

На основу ове табеле чини се да постају јаснији: а) разлози губљења имперфекта; б) разлози уопштавања перфекта; в) разлози одржавања аориста.

Наиме:

а) Имперфекат има највише дистинктивних својстава у односу на остала два члана система: он је видски рестриктиван на несвршене глаголе и уз то се, за разлику од аориста и перфекта, усредсређује на ток радње, а не на њене границе или завршне моменте. С друге стране, имперфекат је са аористом повезан регресивном темпоралном оријентацијом. Овим постаје јасно како су и аорист и перфекат, заједно са презентом, могли преузети низ имперфекатских функција. Тако је ток радње која се вршила у прошлости исказив и релативним презентом (Он сеђаме јуче на тераси: Седи он јуче на тераси), али и перфектом несвршених глагола (Он сеђаше јуче на тераси : Он је седео јуче на тераси). У одређеним случајевима, уколико фокус није на завршености, него на временској локализацији са регресивном темпоралном 
оријентацијом, имперфекат је замењив и аористом (Он сеђаше јуче на тераси : Он седе јуче на тераси).

б) Перфекат од сва три члана система има најуниверзалније карактеристике: прогресивном темпоралном оријентацијом створен је баланс између две тежње: радња је одређена као прошла (за ово је задужен радни глаголски придев), али се везује за ТГ (за ово је задужена копула). Тако, перифрастична форма допушта поливалентност, те нагласак у различитим приликама може бити на претериталној компоненти или на њеној актуелизацији преко копуле. Ова чињеница с једне стране даје предност перфекту у односу на регресивно усмерене аорист и имперфекат, али га са друге стране на известан начин чини статичним (за овакав „осећај” по свој прилици је најзаслужнији презент из копуле - њено изостављање (пример крњег перфекта) као да ову претпоставку потврђује). С друге стране, као што је већ речено, перфекат углавном може добро заменити имперфекат у неким од његових базичних функција. Он то може учинити и са аористом, али ће том приликом доћи до другачијих резултата (в. ниже). Такође, перфектом се никако не инсистира на временској локализацији радње, нити на било каквим сличним додатним параметрима. ${ }^{17}$

в) Аорист је најзанимљивији члан претериталног система. С једне стране избегао је, услед недостатка (строге) видске рестрикције, судбину имперфекта, али је и сам са друге стране потиснут ка периферији система од стране перфекта. На његовом примеру постаје доста јасније да је питање темпоралне оријентације, поред прилика везаних за глаголски вид, одиграло најважнију улогу у преструктурирању система претериталних времена. Битку је, рекло би се, у потпуности добио перфекат са својом прогресивном темпоралном оријентацијом. Међутим, изгледа да је један моменат био пресудан у очувању аориста, барем када је реч о приликама у српском темпоралном систему, а то је истицање завршне тачке, тј. финалне секвенце неке радње. Специфичност аориста у овом погледу изванредна је. Будући да има регресивну темпоралну оријентацију, те да у исто време упућује на финалну компоненту неке радње, може се рећи како аорист успева да фиксира једну тачку у тренутку пре времена говорења. ${ }^{18}$ Ова чињеница аористу, за разлику од „статичног” перфекта, успева да прибави статус ,динамичног” времена, из чега происходе (најмање) две прагматичке импликације: неочекиваност и доживљеност. ${ }^{19}$ Управо из разлога што се фокусира на финалну секвенцу радње, аорист се може разумети и у резултативном кључу. За разлику од перфекта, који би у том случају

${ }^{17} \mathrm{O}$ нпр. лексичким показатељима евиденцијалности в. Поповић 2010.

${ }^{18}$ У овом смислу неизбежно искрсава паралелизам у односу на појаве у флексији, тј. на сличност оваквог аорисног значења са значењем које има акузатив у служби одредбе завршетка места кретања. По таквој аналогији перфекат би могао бити паралелан са „статичним” опозитом акузативу - локативом (уп. однос у град : у граду).

${ }^{19} \mathrm{O}$ овом питању, са знатно више нијанси, в. Станојевић/Ашић 2007. 
нагласио актуелност резултата одређене радње, аорист у први план истиче завршни тренутак, онај у ком одређено дејство добија на својој заокружености и завршености (нарочито су у овом погледу занимљиви глаголи који означавају завршетак кретања; уп. Марко је дошао : Марко дође). ${ }^{20}$ Из оваквих особина аориста произлази погодност његове употребе при формирању приповедачког низа, као и способност за означавање будућих радњи.

\section{ЛИТЕРАТУРА}

Арсенијевић 2013: Бобан Арсенијевић, Временско и аспектуално значење аориста, Српски језик, XVIII, 253-263.

Белић 1925-1926: Александар Белић, Аорист имперфективних глагола, Јужнословенски филолог, V, 171-182.

Белић 1926-1927: Александар Белић, О употреби времена у српскохрватском језику, Јужнословенски филолог, VI, 102-132.

Бунина 1959: Ирина Константиновна Бунина, Система времен старославянского глагола, Москва: Издательство Академии наук СССР.

Вуковић 1967: Jovan Vuković, Sintaksa glagola: studije, Sarajevo: Zavod za izdavanje udžbenika.

Ивић М. 1958: Милка Ивић, Систем личних глаголских облика за обележавање времена у српскохрватском језику, Годишњак Филозофског факултета у Новом Саду, III, 139-152.

Ивић П. 1953-1954: Павле Ивић, Систем значења основних претериталних времена у говору Галипољских Срба, Јужнословенски филолог, XX, 228-262.

Милошевић 1978: Ксенија Милошевић, О проучавању временских глаголских облика у сербокроатистици, Зборник Матище српске за филологију и лингвистику, XXI/2, 93-121.

Плунгјан/Урманчијева 2017: Владимир Александрович Плунгян, Анна Юрьевна Урманчиева, Перфект в старославянском: был ли он результативным?, Slovene, 6/2, 13-56.

Поповић 2010: Људмила Поповић, Категорија евиденцијалности у српском и украјинском језику, Зборник Матице српске за славистику, $77,17-49$.

${ }^{20}$ Резултативни аорист потпуно је уобичајен и у текстовима са почетака словенске писмености (детаљније Плунгјан/Урманчијева 2017: 40-41). 
Сладојевић 1953-1954: Петар Сладојевић, О имперфекту у српскохрватском језику, Јужнословенски филолог, ХХ, 213-228.

Сладојевић 1955-1956: Петар Сладојевић, О значењу аориста у српскохрватском језику, Јужнословенски филолог, XXI, 131-136.

Сладојевић 1966: Петар Сладојевић, О основним временским категоријама употребе глаголских облика у српскохрватскоме језику, Београд: Научна књига.

Станојевић 2007: Веран Станојевић, Аорист у српском и у француском језику: семантичке и прагматичке разлике, Научни састанак слависта у Вукове дане, 36/1, 123-136.

Станојевић/Ашић 2007: Веран Станојевић, Тијана Ашић, О употреби времена у разговорном српском језику - зашто аорист ипак опстаје? у: Српски језик, књижевност и уметност, Зборник радова са научног скупа одржаног на Филолошко-уметничком факултету у Крагујевиу (31. X-01. ХІ 2006). Книга II: Српска реалистичка прича (ур. одбор Р. Симић, Д. Иванић, М. Ковачевић), Крагујевац, 155-171.

Станојевић 2019: Веран Станојевић, Le temps et l'aspect en français et en serbe / Време и аспекат у франиуском и српском језику, Београд: Филолошки факултет.

Станојевић/Ђурић 2019: Веран Станојевић, Љубица Ђурић, Аспекат као фазна категорија и резултативност у француском и српском језику, Српски језик, XXIV, 221-233.

Стевановић 1967: Михаило Стевановић, Функиије и значења глаголских времена, Београд: Научно дело.

Стојановић 2018: Стефан Стојановић, О основном значењу српског перфекта активне дијатезе и његовој типолошкој класификацији, Јужнословенски филолог, LXXIV/2, 109-138.

\section{ON THE BASIC MEANINGS AND RELATIONS INSIDE THE SYSTEM OF PRETERITAL TENSES IN THE SERBIAN LANGUAGE}

\section{Summary}

The paper analysis the meaning and relations between the basic members of the system of the preterital tenses in the Serbian language - imperfect, aorist and perfect. Using, but also deepening the stands of previous researchers in particular aspects, the author seeks 
to reconstruct the initial semantic characteristics of the three tenses in order to better understand the evolution of the system, primarily through processes as loss of imperfect, specialization of aorist, and generalization of perfect. Issues of temporal orientation and punctual-durative (non-)restrictiveness, which were there from the beginning, give every indication of being crucial in the transformation of the semantic characteristic in forms for expressing past actions. As a result, perfect tense, which is progressively temporally oriented and punctual-durative non-restricting form, took predominance over the other members of the system.

Key words: Serbian language, verbal tenses, system of preterital tenses, imperfect, aorist, perfect. 